\title{
Myxopapillary Ependymoma
}

National Cancer Institute

\section{Source}

National Cancer Institute. Myxopapillary Ependymoma. NCI Thesaurus. Code C3697.

A slow growing, WHO grade I glioma which generally occurs in young adults. It arises almost exclusively in the conus medullaris, cauda equina, and filum terminale of the spinal cord. It generally has a favorable prognosis and is characterized histologically by tumor cells arranged in a papillary manner around vascularized mucoid stromal cores. (Adapted from $\mathrm{WHO}$ ). 